\title{
UPAYA PENINGKATAN PENGETAHUAN IBU HAMIL MELALUI PEMANFAATAN BUKU KIA DI WILAYAH KERJA PUSKESMAS KOTA TANJUNGPINANG
}

\author{
Melly Damayanti \\ Prodi DIII Kebidanan, Poltekkes Kemenkes Tanjungpinang, Indonesia \\ Email: apriyandimelly@gmail.com
}

\begin{abstract}
The MCH Handbook has a function as a communication tool between health workers and patients, thus increasing community participation in controlling maternal health. The use of KIA books is one of the strategies to empower the community, especially families, to maintain health and obtain quality health services. The MCH handbook is a communication tool, because health workers can remind important records that can be read by other health workers, mothers and families. The community service activities were held in September - November 2018 with counseling methods, practice of filling out the MCH books and mentoring with a total of 30 participants of pregnant women in the Tanjungpinang Community Health Center Working Area. The implementation of activities starting with the pretest, counseling, the practice of filling out the MCH books, mentoring for 4 weeks and evaluating through posttest, The percentage increase in knowledge of pregnant women about MCH Handbook is 29\%.
\end{abstract}

Keyword : : utilization of the MCH Handbook, knowledge of pregnant women.

\begin{abstract}
ABSTRAK
Buku KIA berfungsi sebagai alat komunikasi antara tenaga kesehatan dengan pasien, sehingga dapat meningkatkan partisipasi masyarakat dalam mengontrol kesehatan ibu. Penggunaan buku KIA merupakan salah satu strategi pemberdayaan masyarakat terutama keluarga, untuk memelihara kesehatan dan mendapatkan pelayanan kesehatan yang berkualitas. Buku KIA disebut sebagai alat komunikasi, karena tenaga kesehatan dapat mengingatkan catatan-catatan penting yang dapat dibaca oleh tenaga kesehatan lain dan ibu serta keluarga. Kegiatan pengabdian kepada masyarakat ini dilaksanakan pada bulan September - November 2018 dengan metode penyuluhan, praktik pengisian buku KIA dan pendampingan dengan total 30 peserta ibu hamil yang berada di Wilayah Kerja Puskesmas Kota Tanjungpinang. Pelaksanaan kegiatan dimulai dengan pretest, penyuluhan, praktik pengisian buku KIA, pendampingan selama 4 minggu dan evaluasi melalui posttest. Persentase peningkatan pengetahuan ibu hamil tentang Buku KIA sebesar 29\%.
\end{abstract}

Kata kunci : Peningkatan pengetahuan ibu hamil, pemanfaatan buku KIA 


\section{PENDAHULUAN}

Buku KIA merupakan alat untuk mendeteksi secara dini adanya gangguan atau masalah kesehatan ibu dan anak, alat komunikasi dan penyuluhan dengan informasi yang penting bagi ibu, keluarga dan masyarakat mengenai pelayanan kesehatan ibu dan anak termasuk rujukannya dan paket (standar) pelayanan KIA, gizi, imunisasi dan tumbuh kembang balita. Penerapan Buku KIA secara benar akan berdampak pada peningkatan pengetahuan ibu dan keluarga akan kesehatan ibu dan anak, menggerakan dan memberdayakan masyarakat untuk hidup sehat, meningkatkan akses masyarakat terhadap pelayanan kesehatan yang berkualitas serta meningkatkan sistem survailan, monitoring dan informasi kesehatan. (Haqiwara, 2013; Kemenkes RI, 2016; Nakamura, 2010).

Hasil analisis yang telah dilakukan dalam Riset Kesehatan Dasar pada tahun 2013, menunjukkan bahwa $80,8 \%$ mempunyai buku KIA, namun yang bisa menunjukkan hanya 40,4\%.H al ini menunjukkan bahwa kepemilikan buku KIA masih di bawah target standar pelayanan yaitu sebesar $100 \%$. Beberapa masalah seputar Buku KIA di Indonesia antara lain: masih ada ibu hamil yang tidak memiliki Buku KIA, tidak dimanfaatkannya Buku KIA oleh ibu hamil dan keluarga sebagai media edukasi, tidak lengkapnya pengisian Buku KIA, Buku KIA disimpan oleh kader atau tenaga kesehatan, dan lain-lain sebagainya. (Riskesdas, 2013).

Buku KIA dapat dijadikan sebagai salah satu media dalam memberikan informasi kesehatan bagi ibu hamil. Melalui Buku KIA, ibu lebih memahami dan bersedia melaksanakan informasi yang ada di dalamnya, meliputi pola nutrisi yang harus dikonsumsi sehari-hari untuk memenuhi kebutuhan selama masa hamil, minum tablet $\mathrm{Fe}$ sesuai aturan untuk mencegah anemia, menghindari hal-hal yang membahayakan kehamilannya dan memeriksakan kehamilan secara rutin untuk memantau kesejahteraan kehamilannya, serta deteksi dini adanya resiko kehamilan. Pemanfaatan buku KIA dengan maksimal diharapkan dapat meningkatkan derajat kesehatan ibu dan janin yang dikandungnya (Ainiyah, 2017; Kurniasari, 2017; Noviyanti, 2015; Sistiarani, 2014).

Program pengabdian kepada masyarakat ini dilakukan pada bulan September November 2018 di Wilayah Kerja Puskesmas Kota Tanjungpinang. Kegiatan ini diharapkan dapat meningkatkan pengetahuan ibu hamil tentang Buku KIA, khususnya tentang kehamilan, persalinan, nifas dan menyusui, serta pemantauan pertumbuhan dan perkembangan bayi-balita.

\section{METODE}

Metode yang digunakan dalam kegiatan ini adalah penyuluhan, praktik cara pengisian Buku KIA oleh ibu hamil serta pendampingan kepada ibu hamil selama 4 minggu. Adapun pelaksanaan kegiatan pengabdian masyarakat sebagai berikut:

1. Persiapan Kegiatan

Dalam tahap ini dilakukan :

a. Survey tempat pelaksanaan kegiatan di Wilayah Kerja Puskesmas Kota Tanjungpinang

b. Pembuatan proposal dengan judul "Upaya Peningkatan Pengetahuan Ibu Hamil melalui Pemanfaatan Buku KIA di Wilayah Kerja Puskesmas Kota Tanjungpinang"

c. Penyelesaian administrasi perizinan tempat pelaksanaan kegiatan pengabdian masyarakat di Puskesmas Kota Tanjungpinang.

d. Menyepakati jadwal pelaksanaan kegiatan dengan pihak puskesmas 
e. Mengumpulkan materi dan membuat media penyuluhan mengenai Buku KIA

2. Pelaksanaan Kegiatan

Tabel 1 Pelaksanaan Kegiatan Pengabdian kepada Masyarakat

\begin{tabular}{|c|c|c|c|c|}
\hline Kegiatan & Metode & Waktu & Alat & Sasaran \\
\hline $\begin{array}{l}\text { Pengisian kusioner } \\
\text { mengenai Buku KIA } \\
\text { oleh ibu hamil } \\
\text { (pretest) dan menilai } \\
\text { kelengkapan } \\
\text { pengisian Buku KIA } \\
\text { serta penyuluhan } \\
\text { mengenai Buku KIA }\end{array}$ & $\begin{array}{l}\text { Pretest, } \\
\text { ceramah, } \\
\text { tanya } \\
\text { jawab, dan } \\
\text { praktik } \\
\text { pengisian } \\
\text { Buku KIA }\end{array}$ & $\begin{array}{l}\text { Sabtu, } \\
\text { 06 Oktober } \\
2018\end{array}$ & $\begin{array}{l}\text { Kuesioner, } \\
\text { LCD, Laptop, } \\
\text { Lembar balik, } \\
\text { leaflet, poster, } \\
\text { Buku KIA }\end{array}$ & Ibu hamil \\
\hline $\begin{array}{l}\text { Pendampingan dan } \\
\text { penyuluhan mengenai } \\
\text { informasi kesehatan } \\
\text { ibu hamil dan ibu } \\
\text { bersalin, }\end{array}$ & $\begin{array}{l}\text { Ceramah, } \\
\text { tanya } \\
\text { jawab, dan } \\
\text { praktik } \\
\text { pengisian } \\
\text { Buku KIA }\end{array}$ & $\begin{array}{l}\text { Sabtu, } \\
13 \text { Oktober } \\
2018\end{array}$ & $\begin{array}{l}\text { LCD, Laptop, } \\
\text { Lembar balik, } \\
\text { leaflet, poster, } \\
\text { Buku KIA }\end{array}$ & Ibu hamil \\
\hline $\begin{array}{l}\text { Pendampingan dan } \\
\text { penyuluhan mengenai } \\
\text { informasi kesehatan } \\
\text { ibu nifas dan Keluarga } \\
\text { Berencana }\end{array}$ & $\begin{array}{l}\text { Ceramah, } \\
\text { tanya } \\
\text { jawab, dan } \\
\text { praktik } \\
\text { pengisian } \\
\text { Buku KIA }\end{array}$ & $\begin{array}{l}\text { Sabtu, } \\
20 \text { Oktober } \\
2018\end{array}$ & $\begin{array}{l}\text { LCD, Laptop, } \\
\text { Lembar balik, } \\
\text { leaflet, poster, } \\
\text { Buku KIA, alat } \\
\text { peraga (alat } \\
\text { kontrasepsi) }\end{array}$ & Ibu hamil \\
\hline $\begin{array}{l}\text { Pendampingan dan } \\
\text { penyuluhan mengenai } \\
\text { informasi kesehatan } \\
\text { anak. }\end{array}$ & $\begin{array}{l}\text { Ceramah, } \\
\text { tanya } \\
\text { jawab, dan } \\
\text { praktik } \\
\text { pengisian } \\
\text { Buku KIA } \\
\end{array}$ & $\begin{array}{l}\text { Sabtu, } \\
27 \text { Oktober } \\
2018\end{array}$ & $\begin{array}{l}\text { LCD, Laptop, } \\
\text { Lembar balik, } \\
\text { leaflet, poster, } \\
\text { Buku KIA }\end{array}$ & Ibu hamil \\
\hline $\begin{array}{l}\text { Pendampingan } \\
\text { evaluasi kegiatan }\end{array}$ & $\begin{array}{l}\text { Tanya } \\
\text { jawab, } \\
\text { posttest }\end{array}$ & $\begin{array}{l}\text { Sabtu, } \\
03 \\
\text { November } \\
2018\end{array}$ & $\begin{array}{l}\text { Kuesioner, } \\
\text { LCD, Laptop, } \\
\text { Buku KIA }\end{array}$ & Ibu hamil \\
\hline
\end{tabular}

3. Evaluasi Kegiatan

Evaluasi kegiatan bertujuan untuk mengetahui perkembangan hasil kegiatan pengabdian masyarakat. Evaluasi yang dilakukan berupa pengisian kuesioner oleh ibu hamil mengenai Buku KIA (posttest) dan menilai kelengkapan pengisian Buku KIA.

4. Penyusunan laporan kegiatan

Pada tahap ini dilakukan penyusunan laporan pelaksanaan kegiatan pengabdian kepada masyarakat. 


\section{HASIL DAN PEMBAHASAN}

Kegiatan pengabdian masyarakat yang telah dilaksanakan ini merupakan kegiatan yng melibatkan banyak pihak, diantaranya Poltekkes Kemenkes Tanjungpinang sebagai penyelenggara dalam rangka pelaksanaan Tri Dharma Perguruan Tinggi dan Puskesmas Kota Tanjungpinang. Kegiatan ini berupa penyuluhan dan pendampingan kepada $30 \mathrm{ibu}$ hamil. Kegiatan penyuluhan dilakukan di Puskesmas Kota Tanjungpinang, sedangkan pendampingan dilakukan di rumah ibu hamil selama 4 minggu. Adapun langkah-langkah kegiatan sebagai berikut:

1. Persiapan yang meliputi: menyusun proposal yang mulai dilaksanakan pada bulan September 2018. Setelah itu dilakukan seminar proposal dan emperbaiki proposal yang dilakukan di Poltekkes Kemenkes Tanjungpinang. Setelah perbaikan proposal diterima dan disahkan oleh Direktur Poltekkes Kemenkes Tanjungpinang, selanjutnya kegiatan pengabdian masyarakat ini dilanjutkan pada tahap pelaksanaan.

2. Tahap pelaksanaan diawali dengan suatu pertemuan formal dengan pihak puskesmas pada tanggal 02 Oktober 2018. Kegiatan ini bertujuan untuk melakukan survey awal dan pengumpulan data. Pihak puskesmas akan memfasilitasi pelaksanaan kegiatan ini. Penyuluhan kepada ibu hamil akan dilaksanakan di Puskesmas pada tanggal 06 Oktober 2018.

3. Setelah pihak puskesmas memfasilitasi kegiatan penyuluhan dengan mengumpulkan 30 orang ibu hamil, kemudian tim pengabdian masyarakat melakukan penyuluhan serta praktik pengisian Buku KIA. Sebelum dilakukan penyuluhan, dilakukan pengisian kuesioner oleh ibu hamil (pretest). Setiap minggu dilakukan pendampingan kepada ibu hamil selama 1 bulan.

4. Setelah 4 minggu pendampingan, dilakukan evaluasi kegiatan dalam bentuk pengisian kuesioner (posttest) dan memeriksa kelengkapan pengisian Buku KIA.

Tabel 2 Hasil Evaluasi Kegiatan Pengabdian kepada Masyarakat

\begin{tabular}{lccc}
\hline \multicolumn{1}{c}{ Sub Topik } & $\begin{array}{c}\text { Mean } \\
\text { Pretest }\end{array}$ & $\begin{array}{c}\text { Mean } \\
\text { Posttest }\end{array}$ & $\begin{array}{c}\text { Persentase } \\
\text { Kenaikan }\end{array}$ \\
\hline $\begin{array}{l}\text { Pemahaman ibu tentang Konsep Dasar } \\
\text { Buku KIA }\end{array}$ & 55 & 87 & $32 \%$ \\
\hline $\begin{array}{l}\text { Pemahaman ibu tentang manfaat Buku } \\
\text { KIA }\end{array}$ & 58 & 80 & $22 \%$ \\
\hline $\begin{array}{l}\text { Pemahaman ibu tentang cara } \\
\text { menggunakan Buku KIA }\end{array}$ & 48 & 83 & $39 \%$ \\
\hline $\begin{array}{l}\text { Pemahaman ibu tentang Kesehatan } \\
\text { Ibu }\end{array}$ & 49 & 79 & $30 \%$ \\
\hline $\begin{array}{l}\text { Pemahaman ibu tentang Kesehatan } \\
\text { Bayi/ Anak }\end{array}$ & 52 & 78 & $26 \%$ \\
\hline Pemahaman Buku KIA & 51.5 & 80.5 & $29 \%$ \\
\hline
\end{tabular}

Hasil yang dicapai dalam kegiatan pengabdian kepada masyarakat ini yaitu meningkatnya pengetahuan ibu hamil tentang Buku KIA sebesar 29\%. Selain itu, adanya peningkatan upaya pemanfatan buku KIA oleh ibu hamil yang dapat dilihat dari kelengkapan pengisian Buku KIA dan digunakannya Buku KIA sebagai instrumen pemantauan kesehatan ibu dan balita. 


\section{SIMPULAN}

Kegiatan pengabdian masyarakat ini telah dilakukan kepada $30 \mathrm{ibu}$ hamil yang ada di Wilyah Kerja Puskesmas Kota Tanjungpinang. Pelaksanaan kegiatan ini dimulai dengan pretest, penyuluhan, praktik pengisian buku KIA, pendampingan selama 1 bulan dan evaluasi melalui posttes. Persentase peningkatan pengetahuan ibu hamil tentang Buku KIA sebesar 29\% dan adanya peningkatan upaya pemanfaatan Buku KIA oleh ibu.

\section{DAFTAR PUSTAKA}

1. Ainiyah NH, Hakimi M, Anjarwati. The Use of Maternal and Child Health (MCH) Handbook Improves Healthy Behavior of Pregnant Women.

2. Haqiwara A, Ueyama M, Ramlawi A, Sawada Y. Is the Maternal and Child Health $(\mathrm{MCH})$ Handbook Effective in Improving Health-related Behavior? Evidence from Palestine. Journal Public Health Policy. Vol. 34 No.1. January 2013. Hal 31-45.

3. Kementerian Kesehatan RI. 2013. Laporan hasil Riset Kesehatan Dasar (Riskesdas) tahun 2013. Jakarta: Badan Penelitian dan Pengembangan Kesehatan Kementerian Kesehatan RI.

4. Kementerian Kesehatan RI. 2016. Buku Kesehatan Ibu dan Anak. Jakarta: Kemenkes RI.

5. Kurniasari L. Buku KIA dan Pemanfaatan untuk Peningkatan Kesehatan Ibu dan Anak. Jurnal Kesehatan Masyarakat.Vol. 03 No. 01 Januari 2017. Hal. 9-18.

6. Nakamura Y. Maternal and Child Health Handbook in Japan. JMAJ.Vol. 59 No.4. JulyAugust 2010. Hal. 259-265.

7. Novianti NPY. Pengetahuan, Sikap dan Pemanfaatan Buku KIA oleh Ibu Hamil di Wilayah Kerja Puskesmas Denpasar Selatan. Thesis. Universitas Udayana. 2015.

8. Nurhayati, S dan Sistiarani, C.Faktor yang Berhubungan dengan Peran Bidan Desa dalam Pengisian Buku KIA. Prosiding Seminar Nasional Pangan, Gizi dan Kesehatan Kearifan Lokal. Purwokerto: LPPM Universitas Jenderal Soedirman; 2011.

9. Pandora J, Kartasurya MI, Winami S. Penggunaan Buku KIA sebagai Media Edukasi pada Ibu Hamil. Jurnal Kesehatan Masyarakat. Vol. 6 No.2. April 2018. Hal. 63-73.

10. Sari M., 2017. Pemanfaatan Buku KIA melalui Pendampingan Mahasiswa pada Ibu Hamil dan Ibu yang Memiliki Anak Usia Bawah Dua Tahun (Baduta). BBPK Jakarta.

11. Sistiarani C dan Gamelia E. Analisis Pencapaian Indikator KIA di Puskesmas Kalibagor. Jurnal Kesehatan Masyarakat, Vol.4 No.6. 2012. Hal.120-95.

12. Sistiarani C., Gamelia E., Hariyadi B. Analisis Kualitas Penggunaan Buku Kesehatan Ibu Anak. Jurnal Kesmas Indonesia, Vol. 10 No.1.2014: 14-20.

13. Sistiarani C, Gamelia E, Sari DUP. Fungsi Pemanfaatan Buku KIA terhadap Pengetahuan Kesehatan Ibu dan Anak pada Ibu. Jurnal Kesehatan Masyarakat Nasional. Vol.8 No.8. Mei 2014.

14. World Health Organization (WHO). 2016. WHO Recommendations on Antenatal Care for a positive Pregnancy Experience. Luxembourg. 